\title{
Evaluasi Kualitas Telur Itik Talang Benih dengan Jenis Daun dan Lama Penyimpanan yang Berbeda
}

\author{
Jekson Fresli, Wismalinda Rita, Nur Hidayah* \\ Program Studi Peternakan, Fakultas Pertanian, Univ. Muhammadiyah Bengkulu \\ Jl. Bali, Kelurahan Kampung Bali, Kecamatan Teluk Segara, Kota Bengkulu, 38119 \\ *Email korespondensi: nurhidayah@umb.ac.id
}

(Diterima: 30-04-2019; disetujui 12-07-2019)

\begin{abstract}
ABSTRAK
Tujuan penelitian ini mengetahui jenis daun dan lama penyimpanan terbaik pada kualitas telur itik talang benih konsumsi. Rancangan penelitian yang digunakan adalah rancangan acak lengkap (RAL) pola faktorial dengan 2 faktor dan 3 kali ulangan. Faktor pertama yaitu jenis daun (daun sirsak dan jambu biji) dan faktor kedua yaitu lama penyimpanan $(0,15$, dan 30 hari). Parameter yang diamati yaitu warna kuning telur, albumen indeks, yolk indeks, dan haugh unit. Data dianalisis menggunakan ANOVA dan perbedaan antara perlakuan diuji lanjut dengan uji DMRT. Hasil penelitian menunjukan bahawa tidak ada interaksi antara jenis daun dan lama penyimpanan terhadap warna kuning telur, albumen indeks, yolk indeks, dan haugh unit. Daun sirsak lebih mampu mempertahankan warna kuning telur dibandingkan daun jambu biji $(\mathrm{P}<0,05)$, namun tidak berbeda nyata $(\mathrm{P}>0,05)$ terhadap albumen indeks, yolk indeks, dan haugh unit. Lama penyimpanan sangat berpengaruh nyata $(\mathrm{P}<0,01)$ terhadap warna kuning telur, albumen indeks, yolk indeks, dan haugh unit. Dapat disimpulkan bahwa daun sirsak memiliki kemampuan lebih baik dalam mempertahankan warna kuning telur itik talang benih. Penyimpanan telur sebaiknya dilakukan sampai batas 15 hari karena albumen indeks, yolk indeks, dan haugh unit memiliki mutu 2.
\end{abstract}

Kata Kunci: daun, itik talang benih, kualitas telur, lama penyimpanan

\begin{abstract}
The amis of this study to determine the type of leaves and the best storage time for the quality of talang benih duck's egg consumption. The research was design in factorial completely randomized design with 2 factors and 3 replications. The first factor is type of leaves (soursop and guava) and the second factor is storage time (0,15 and 30 days). Variables observed were yolk color, albumen index, yolk index, and haugh unit. Data were analyzed using ANOVA and differences between treatments were tested by DMRT test. The results showed that there was no interaction between leaves type and storage time for yolk color, albumen index, yolk index, and haugh unit. Soursop leaves are more able to maintain the color of egg yolk than guava leaves $(\mathrm{P}<0.05)$, but not significantly different $(\mathrm{P}>0.05)$ to the albumen index, yolk index, and haugh unit. Storage time had strong significant effect $(\mathrm{P}<0.01)$ on egg yolk color, albumen index, yolk index, and haugh unit. It is concluded that soursop leaves have a better ability to maintain the color of duck egg yolk. Egg storage time should be carried out up to 15 days because albumen index, yolk index, and haugh unit had quality 2.
\end{abstract}

Key words: egg quality, leaves, storage time, talang benuh duck 


\section{PENDAHULUAN}

Telur merupakan salah satu protein hewani yang digemari masyarakat. Telur memiliki kelebihan yaitu nilai gizi yang tinggi dan harganya terjangkau, namun umur simpan singkat pada suhu ruang. Menurut Cornelia et al., (2014), telur dalam suhu ruang mampu tahan 10-14 hari, kemudian akan terjadi kerusakan yang berakibat berat telur berkurang, komposisi kimia berubah dan isi telur menjadi encer.

Beberapa cara dapat pengawetan yang dapat dilakukan yaitu dengan metode perendaman menggunakan bahan alami daundaunan. Hasil penelitian Kartina (2017) melaporkan bahwa telur yang direndam daun sirsak sebanyak 25\% mampu mempertahankan kualitas telur pada hari ke 14. Perendaman telur dengan ekstrak daun sirsak mempu mempertahankan kualitas telur hingga hari ke 35 (Tamal \& Anggraeni, 2016), dan perendaman telur dengan daun jambu biji dapat mempertahankan mutu atau kualitas telur hingga minggu ke tiga (Mulyadi, 2010).

Daun sirsak (Annona muricata L) memiliki kandungan tanin sehingga sifat kerabang telur berubah menjadi impermeable, sehingga menghambat keluarnya air, gas, menghambat mikroba masuk. Ekstrak daun sirsak mengandung flavanoid yang dapat berfungsi sebagai antioksidan alami dan mempunyai anti bakteri (Rohana, 2000). Maryati et al. (2008) melaporkan bahwa terdapat asam kratogolat, vitamin, asam oleanolat, asam guajaverin, asam ursolat, minyak atsiri dan asam psidiolat pada daun jambu biji (Psidium guajava Linn).

Provinsi Bengkulu merupakan daerah yang kaya tanaman herbal. Banyak tananman herbal liar yang belum dimanfaatkan masyarakat. Contoh tanaman herbal yang banyak tersedia di Bengkulu yaitu sirsak dan jambu biji. Provinsi Bengkulu juga memiliki plasma nutfah yaitu itik talang benih. Itik talang benih merupakan itik duwi guna yang mampu memproduksi telur tinggi walaupun dengan kualitas makanan yang rendah serta tahan terhadap perubahan lingkungan yang ekstrim dan wabah penyakit (Suharnas, 2006).

Belum banyak penelitian mengenai penggunaan daun sirsak dan daun jambu biji sebagai pengawet alami pada telur ituik talang benih. Serta sampai berapa lama telur itik talang benih tahan disimpan pada suhu ruang belum banyak diteliti. Oleh sebab itu tujuan penelitian ini mengevaluasi kualitas telur itik talang benih dengan menggunakan jenis daun dan lama penyimpana yang berbeda. Kualitas telur yang diamati berupa warna kuning telur, albumen indeks, yolk indeks, dan haugh unit.

\section{MATERI DAN METODE}

Penelitian ini dilakukan di Laboratorium Program Studi Peternakan, Fakultas Pertanian, Universitas Bengkulu. Rancangan penelitian yang digunakan adalah rancangan acak lengkap (RAL) pola faktorial dengan 2 faktor dan 3 kali ulangan. Faktor pertama yaitu jenis daun (daun sirsak dan jambu biji) dan faktor kedua yaitu lama penyimpanan $(0,15$, dan 30 hari). Parameter yang diamati yaitu warna kuning telur, albumen indeks, yolk indeks, dan haugh unit. Data hasil penelitian dianalisis dengan ANOVA menggunakan software SPSS versi 16. Jika perlakuan berpengaruh nyata dilanjutkan uji beda antar perlakuan menggunakan uji DMRT.

Tahapan penelitian meliputi: 1) pembuatan larutan daun (daun yang digunakan adalah daun sirsak dan jambu biji yang agak tua. Daun tersebut dicuci bersih lalu ditimbang sesuai perlakuan $25 \%$. 2) tahap persiapan telur (telur itik talang benih yang digunakan merupakan jenis telur konsumsi berasal dari itik UPTD talang kering, Provinsi Bengkulu. Berat dan ukuran telur yang dipilih yaitu yang sama, dibersihkan dari kotoran. pembersihan telur dari kotoran menggunakan air bersih kemudian telur dilap hingga kering dan bersih.Jumlah yang digunakan sebanyak 90 butir, dimana jumlah ini sesuai dengan kebutuhan perlakuan yaitu 2 faktor x 3 ulangan sehingga terdapat 18 unit perlakuan, setiap unit perlakuan menggunakan 5 butir telur. 3) tahap perendaman telur (perendaman telur itik talang benih menggunakan wadah toples berukuran sedang. Masing-masing toples berisi 5 telur dan 1 liter larutan daun yang telah disiapkan. Perendaman dilakukan selama 24 jam sesuai dengan penelitian terbaik (Tamal \& Anggraeni, 2016). 4) tahap penyimpanan telur (setelah perendam telur dibersihkan menggunakan tisu hingga kering dan bersih, telur diletakan pada rak telur kemudian disimpan pada suhu ruang. Lama penyimpanan telur $0,15,30$ hari). 5) tahap pengukuran kualitas telur (Nurwanto \& Mulyani, 2003) meliputi: warna kuning telur (menggunakan alat yolk colour fan), albumen 
indeks $(\mathrm{mm})=$ tinggi putih telur kental $(\mathrm{mm}) /$ rerata diameter putih telur kental $(\mathrm{mm})$, yolks indeks $(\mathrm{mm})=$ tinggi kuning telur $(\mathrm{mm}) /$ diameter kuning telur (mm), dan haugh unit $=$ $100 \log$ (tinggi putih telur kental $(\mathrm{mm})+7,57-$ 1,7 berat telur $\left.{ }^{0,37}\right)$.

\section{HASIL DAN PEMBAHASAN}

\section{Warna Kuning Telur Itik Talang Benih dengan Perendaman Jenis Daun dan Lama Penyimpanan yang Berbeda}

Tidak ada interaksi antara jenis daun dan lama penyimpanan terhadap warna kuning telur itik talang benih. Daun sirsak lebih mampu mempertahankan warna kuning telur itik talang benih dibandingkan pada daun jambu biji $(\mathrm{P}<0,05)$. Lama penyimpanan sangat berpengaruh $(\mathrm{P}<0,01)$ pada warna kuning telur itik talang benih. Penyimpanan 0 dan 15 warna kuning telur sama pada mutu 1 , namun pada penyimpanan 30 hari warna kuning telur sudah menurun pada mutu 2. Rataan warna kuning telur berdasarkan lama penyimpanan pada penelitian ini berkisar dari $(10,00-11,17)$ yang masih dalam kualitas baik untuk dikonsumsi (Tabel 1). Nugraha et al. (2013) menyatakan bahwa warna kuning telur (11-15) termasuk pada mutu 1, (6-10) mutu 2, dan (1-5) mutu 3.

Daun sirsak nyata memberikan pengaruh yang lebih baik dibandingkan daun jambu biji terhadap warna kuning telur itik talang benih. Hal ini dikarenakan kandungan tanin pada daun sirsak $(28,15 \%)$ lebih tinggi dibandingkan daun jambu biji (12\%) (Chintya \& Utami, 2017 ; Maryati et al., 2008). Karmila et al. (2008) melaporkan bahwa tanin akan bereaksi dengan protein pada kerabang telur sehingga terjadi peroses pelapisan kulit yaitu endapan berwarna coklat yang dapat menutupi pori kerabang telur tersebut menjadi impermeable pada gas dan udara, sehingga mampu memperkecil penguapan air serta hilangnya $\mathrm{CO}_{2}$ melalui kerabang telur, sehingga mampu mempertahankan warna kuning telur. Selain itu diduga persentase tanin terkondensasi dari daun sirsak lebih banyak dibandingkan persentase tanin terhidrolisis sehingga lebih kuat mempertahankan warna kuning telur. Hal ini dikarenakan tanin terkondensasi mampu mengikat protein lebih kuat dan sehingga mampu mempertahankan warna kuning telur lebih sempurna.

Penyimpanan yang berbeda juga mempengaruhi warna kuning telur. Kurtini et al. (2014) melaporkan bahwa semakin lama penyimpanan, kekuatan dan elastisitas membran vitelin menurun yang menyebabkan mudah pecah sehingga warna kuning telur dan indeks kuning telur menurun

\section{Albumen indeks Telur Itik Talang Benih dengan Perendaman Jenis Daun dan Lama Penyimpanan yang Berbeda}

Tidak ada interaksi antara jenis daun dan lama penyimpanan terhadap albumen indeks telur itik talang benih. Daun sirsak dan daun jambu biji tidak memberikan pengaruh yang nyata $(\mathrm{P}>0,05)$ terhadap albumen indeks telur itik talang benih. Lama penyimpanan yang berbeda sangat berpengaruh nyata $(\mathrm{P}<0,01)$ terhadap albumen indeks telur itik talang benih. Penyimpanan 0 hari memiliki albumen indeks pada mutu 1 , sedangkan pada hari 15 dan 30 albumen indeks sudah menurun pada mutu 2. Rataan albumen indeks pada penelitian ini berkisar dari 0,10-0,15 yang masih dalam kualitas baik untuk dikonsumsi (Tabel 2). Berdasarkan Standar Nasional (2008) nilai albumen indeks berkisar 0,134-0,175 merupakan mutu 1; 0,092-0,133 mutu 2; dan 0,05-0,09 mutu 3.

Albumen indeks menurun dengan semakin lamanya penyimpanan. Saraswati (2015) menyatakan bahwa semakin lama penyimpanan menyebabkan penurunan tinggi lapisan putih telur kental dan akhirnya penurunan tersebut akan semakin lambat. Waktu penyimpanan semakin lama menyebabkan pori membesar dan merusak lapisan mukosa. Sehingga masuknya bakteri, gas, dan air lebih mudah yang menyebabkan cepat terjadinya penurunan kualitas dan kesegaran telur. Menurut Jazil et al. (2012) suhu dan kelembaban merupakan faktor yang mempengaruhi kualitas telur. Albumen indeks yang dilaporkan Tamal \& Anggraeni (2016) dengan melakkan perendaman daun sirsak dan penyimpanan selama 14 hari hanya sebesar 0,07 (mutu 3) yang lebih rendah dibandingkan dari hasil penelitian yang didapat. 
Tabel 1. Warna kuning telur itik talang benih dengan perndaman jenis daun dan lama penyimpanan yang berbeda

\begin{tabular}{lcccc}
\hline \multirow{2}{*}{ Jenis Daun } & 0 & Lama Penyimpanan & \multicolumn{2}{c}{ Rata-rata Jenis } \\
\cline { 2 - 4 } Daun
\end{tabular}

Keterangan : $\quad$ Rataan dengan superskrip yang berbeda kolom yang sama menunjukkan perbedaaan nyata $(\mathrm{P}<0,05)$ dan pada baris yang sama menunjukkan perbedaan yang sangat nyata $(\mathrm{P}<0,01)$

Tabel 2. Albumen indeks telur itik talang benih dengan perndaman jenis daun dan lama penyimpanan yang berbeda

\begin{tabular}{lcccc}
\hline \multirow{2}{*}{ Jenis Daun } & \multicolumn{3}{c}{ Lama Penyimpanan } & Rata-rata Jenis \\
\cline { 2 - 4 } & 0 & 15 & 30 & Daun \\
\hline Daun Sirsak & $0,15 \pm 0,01$ & $0,14 \pm 0,02$ & $0,10 \pm 0,01$ & $0,13 \pm 0,03$ \\
Daun Jambu Biji & $0,14 \pm 0,01$ & $0,12 \pm 0,01$ & $0,10 \pm 0,01$ & $0,12 \pm 0,02$ \\
\hline Rata-rata & $0,15 \pm 0,01^{\mathrm{c}}$ & $0,13 \pm 0,01^{\mathrm{b}}$ & $0,10 \pm 0,01^{\mathrm{a}}$ & \\
\hline
\end{tabular}

Keterangan: Rataan dengan superskrip yang berbeda pada baris yang sama menunjukkan perbedaaan yang sangat nyata $(\mathrm{P}<0,01)$

Tabel 3. Yolks indeks telur itik talang benih dengan perndaman jenis daun dan lama penyimpanan yang berbeda

\begin{tabular}{lcccc}
\hline \multirow{2}{*}{ Jenis Daun } & 0 & Lama Penyimpanan & Rata-rata Jenis \\
\cline { 2 - 4 } Daun
\end{tabular}

Keterangan: Rataan dengan superskrip yang berbeda pada baris yang sama menunjukkan perbedaaan yang sangat nyata $(\mathrm{P}<0,01)$

\section{Yolk Indeks Telur Itik Talang Benih dengan Perendaman Jenis Daun dan Lama Penyimpanan yang Berbeda}

Tidak ada interaksi antara jenis daun dan lama penyimpanan terhadap yolks indeks telur itik talang benih. Daun sirsak dan daun jambu biji tidak memberikan pengaruh yang nyata $(\mathrm{P}>0,05)$ terhadap yolks indeks telur itik talang benih. Lama penyimpanan sangat berpengaruh nyata $(\mathrm{P}<0,01)$ terhadap yolk indeks telur itik talang benih. Penyimpanan 0 dan 15 hari yolk indeks pada mutu 2, namun pada penyimpanan 30 hari yolk indeks menurun pada mutu 3. Rataan yolks indeks berdasarkan lama penyimpanan pada penelitian ini $(0,44-0,35)$ yang masih standar aman untuk dikonsumsi (Tabel 3). Berdasarkan Standar Nasional Indonesia (2008), mutu yolks indeks dibagi menjadi 3 bagian yaitu mutu $1(0,458-0,521)$, mutu $2(0,394-0,457)$, dan mutu $3(0,330-0,393)$.

Secara umum yolks indeks mengalami penurunan seiring dengan lamanya penyimpanan. Hal tersebut menunjukan bahwa menurunnya membran vitelin dan encernya kuning telur sebagian besar disebabkan oleh difusi air dari putih telur. Hadjrawati et al. (2011) menyatakan bahwa penurunan elastisitas membrane vitellin disebabkan terjadinya perbedaan tekanan osmosis antara putih telur dan kuning telur yang terus menerus. 
Tabel 4. Haugh unit telur itik talang benih dengan perendaman jenis daun dan lama penyimpanan yang berbeda

\begin{tabular}{lcccc}
\hline \multirow{2}{*}{ Jenis Daun } & \multicolumn{3}{c}{ Lama Penyimpanan } & Rata-rata Jenis \\
\cline { 2 - 4 } & 0 & 15 & 30 & Daun \\
\hline Daun Sirsak & $70,81 \pm 0,71$ & $68,24 \pm 0,58$ & $56,84 \pm 3,64$ & $65,30 \pm 6,71$ \\
Daun Jambu Biji & $70,23 \pm 0,53$ & $66,50 \pm 0,10$ & $57,25 \pm 1,35$ & $64,66 \pm 5,83$ \\
\hline Rata-rata & $70,52 \pm 0,64^{\mathrm{c}}$ & $67,37 \pm 1,03^{\mathrm{b}}$ & $57,05 \pm 2,47^{\mathrm{a}}$ & \\
\hline Keterangan : Rataan dengan superskrip yang berbeda pada baris yang sama menunjukkan & perbedaaan yang \\
& & &
\end{tabular}

Proses ini mengakibatkan terjadinya pembesaran pada diameter kuning telur dan menurunnya elastisitas membran vitelin. Semakin lama penyimpanan, kekuatan memberan vitelin semakin berkurang. Hal tersebut dikarenakan masuknya mikroorganisme pada putih telur menghasilkan enzim proteolitik yang menyebabkan memberan vitelin semakin lemah (Keener et al., 2006).

Nilai yolk indeks pada penelitian ini lebih bagus dibandingkan dengan hasil penelitian Lestari et al. (2011) yang menggunakan daun melinjo (Gentum gnemon Linn) sebagai pengawet alami dengan lama penyimpanan 28 hari memiliki yolk indeks sebesar 0,28-0,30 (mutu > 3). Novika et al. (2017) melaporkan bahwa perendaman telur itik menggunakan daun salam (Syzygium polyantha) dengan lama penyimpanan 14 hari mengasilkan nilai yolk indeks 0,41-0,40 (mutu 2) dan 28 hari 0,33 (mutu 3). Hasil penelitian Azizah et al. (2017) yang menggunakan daun jambu biji (Psidium Guajava) dengan penyimpanan selama 2 minggu memiliki yolk indeks sebesar 0,40-0,50 (mutu 12).

\section{Haugh Unit Telur Itik Talang Benih dengan Perendaman Jenis Daun dan Lama Penyimpanan yang Berbeda}

Tidak ada interaksi antara jenis daun dan lama penyimpanan terhadap haugh unit telur itik talang benih. Jenis daun tidak berpengaruh $(\mathrm{P}>0,05)$ terhadap haugh unit telur itik talang benih. Lama penyimpanan sangat berpengaruh $(\mathrm{P}<0,01)$ terhadap haugh unit telur itik talang benih. Penyimpanan 30 hari memiliki nilai haugh unit yang rendah (mutu 3) sangat berbeda nyata $(\mathrm{P}<0,01)$ dengan lama penyimpanan 0 dan 15 hari (mutu 2). Rataan haugh unit berdasarkan lama penyimpanan pada penelitian ini $(70,52-$ 57,05) yang masih dalam kualitas baik untuk dikonsumsi (Tabel 4). USDA (2000) menyatakan bahwa nilai haugh unit telur itik (>72) mutu 1 , (60-70) mutu 2, (31-60) mutu 3.
Nilai haugh unit dipengaruhi oleh putih telur, semakin encer putih telur maka nilai haugh unit dan kualitas telurnya semakin menurun. Penurunan tinggi putih telur diakibatkan karena adanya kerusakan setruktur gel ovomucin akibat meningkatnya pH telur. Faikoh (2014) menyatakan bahwa nilai haugh unit ditentukan berdasarkan keadaan putih telur, yaitu korelasi antara bobot telur dan tinggi putih telur. Lestari et al. (2013) menyatakan bahwa penurunan nilai haugh unit terjadi karena perubahan suhu, meningkatnya kelembaban yang menyebabkan hilangnya karbondioksida (CO2) dan lamanya penyimpanan.

Hasil penelitian yang sama dilaporkan oleh Azizah et al. (2017) dengan menggunakan daun jambu biji (Psidium guajava) dengan penyimpanan lebih dari 2 minggu (yaitu 28 hari) memiliki nilai haugh unit selama sebesar 62,535,11 (mutu 3). Sedangkan penelitian Mulyadi (2010) dengan menggunakan daun jambu biji dan daun jati yang disimpan selama 3 minggu memiliki nilai haugh unit sebesar 71-60 (mutu 2). Hasil penelitian yang berbeda ini dikarenakan adanya perbedaan konsentrasi daun yang digunakan selama penelitian.

\section{KESIMPULAN}

Tidak ada interaksi antara jenis daun dan lama penyimpanan pada warna kuning telur, albumen indeks, yolk indeks, dan haugh unit telur itik talang benih. daun sirsak memiliki kemampuan lebih baik dalam mempertahankan warna kuning telur itik talang benih. Penyimpanan telur sebaiknya dilakukan sampai batas 15 hari karena albumen indeks, yolk indeks, dan haugh unit memiliki mutu 2.

\section{DAFTAR PUSTAKA}

Azizah, N., M.A. Djaelani, \& S.M. Mardiati. 2017. Kandungan protein, indeks putih telur dan haugh unit telur itik setelah perendaman dengan larutan daun jambu 
biji (Psidium guajava) yang disimpan pada suhu $27^{\circ} \mathrm{C}$. Program Studi Biologi Fakultas Sains dan Matematika Universitas Diponegoro. Semarang.

Badan Standarisasi Nasional. 2008. Telur Ayam Konsumsi. SNI-3926-2008. Jakarta.

Chintya \& B. Utami, 2017. Ekstraksi tannin dari daun sirsak (Anonna muricata l) sebagai pewarna alami tekstil. Jurnal Cis-Trans (JC-T) 1:2449-6573.

Cornelia, A., I. K. Suada \& M. D. Rudyanto. 2014. Perbedaan daya simpan telur ayam rasyang dicelupkan dan tanpa dicelupkanlarutan kulit manggis. Indonesia Medicus Veterinus 3:112-119.

Faikoh, N.E. 2014. Keajaiban Telur. Istana Media. Yogyakarta.

Hadjrawati, J.C. Likadja, \& Hessy. 2012. Pengaruh lama perendaman ekstrak kulit buah kakao dan lama penyimpanan terhadap daya awet telur ayam ras. Agriplus 1:54-62

Jazil, N., A. Hartono, \& S. Mulyadi. 2012. Penurunan kualitas telur ayam ras dengan intensitas warna cokelat kerabang berbeda selama penyimpanan. Fakultas Peternakan dan Pertanian Universitas Diponegoro, Semarang.

Karmila. M., Maryati, \& Jusmawati. 2008. Pemanfaatan daun jambu biji (Psidium guajava L.) sebagai alternatif pengawetan telur ayam ras. UNM. Makasar.

Kartina. 2017. Pengaruh konsentrasi ekstrak daun sirsak sebagai pengawet telur ayam ras dan umur telur terhadap kualitas oganoleptik. Fakultas Peternakan Universitas Hasanuddin. Makasar.

Keener, K. M., C. McAvoy, J. B. Foegeding, P. A. Curtis, K. E. Anderson \& J. A. Osborne. 2006. Effect of testing temperature on internal egg quality measurements. Poultry Sci Association. 85:550-555.

Kurtini, T., K. Nova, \& D. Septinova. 2014. Produksi Ternak Unggas. Edisi Revisi. Aura Printing. Bandar Lampung.
Lestari, Sri, M. Ratmawati, \& G. Syamsudin. 2013. Pengawetan telur dengan perendaman ekstrak daun malinjo (Gnetumgnemon Linn). J. Sains \& Teknologi 13:184-189.

Maryati, Jusmawati, \& M. Karmila. 2008. Pemanfaatan daun jambu biji (Psidium guajava) sebagai alternatif pengawet telur ayam ras. Jurnal Nalar 1: 264-270.

Mulyadi \& Riski. 2010. Kualitas fisik telur ayam ras dan telur itik yang diawetkan dengan ekstrak daun jambu biji (Pisidium guavaja Linn) dan daun jati (Tectona grandis) pada lama penyimpanan yang berbeda. Program Studi Peternakan Fakultas Pertanian Universitas Islam Negeri Sultan Syarif Kasim. Riau.

Novika, Z., M.A. Djaelani, \& S.M. Mardiati. 2017. Kualitas telur itik setelah perendaman dengan ekstrak daun salam (Syzygium polyantha) dan disimpan pada suhu $4^{\circ} \mathrm{C}$. Program Studi Biologi Fakultas Sains Matematika Universitas Diponegoro. Semarang.

Nugraha, F.S., M. Mufti, \& I. Hari. 2013. Kualitas telur itik yang dipelihara secara terkurung basah dan kering di kabupaten cirebon. J. I1m. Pet. 1:726-734.

Nurwanto \& S. Mulyani. 2003. Buku Ajar Dasar Teknologi Hasil Ternak. Fakultas Peternakan Universitas Diponegoro. Semarang.

Rohana, E. 2000. Kajian pengaruh lama perebusan dan konsentrasi tanin terhadap kadar $\mathrm{NaCl}$ telur asin selama penyimpanan. Jurusan Ilmu Produksi Ternak, Fakultas Peternakan, Bogor.

Suharnas. 2006. Karakteristik morfologis dan genetik itik talang benih di bengkulu. Seminar Nasional Teknologi Peternakan dan Veteriner.

Tamal \& M. Anggraeni. 2016. Perendaman ekstrak daun sirsak (Annona muricata linn) sebagai pengawet kualitas telur itik. JPT 4:81-92.

United States Departement of Agriculture USDA. 2000. Egg-grading Manual. Department of Agriculture. Washington. 